\title{
MSME'S DEMOGRAPHIC AS MODERATION IN THE IMPACT OF PERCEPTION AND UNDERSTANDING OF BOOKKEEPING TOWARDS QUALITY OF FINANCIAL REPORT
}

\author{
Cahyani Tunggal Sari ${ }^{1}$ \\ Lukman Ahmad Imron Pahlawi ${ }^{2}$ \\ STIE AUB Surakarta, Indonesia
}

\begin{abstract}
Micro Small Medium Enterprises (MSME) especially in culinary are the main destination of tourist in Surakarta Indonesia. As the tourist destination, MSME must be creative in develop their product. The financial ability is the main source of the owner in develop their business. Bank loan is an alternative in order to improve the financial sorce. Therefore, the MSME's owner need to compile the financial report as one of bank loan requirement. This study is a quantitative research which is use multiple regression analysis using moderation variables. The quality of financial report is the dependent variable. The Independent variables are the MSME's owner perception and understanding about book keeping. This study also enclose the MSME's owner demographic background that consist of educational leverage and business size as the moderating variables. The data is collected from culinary MSME's in Surakarta, Indonesia in the year of 2017. The findings of this research shows that educational leverage and business size are Predictor Moderation Variable. Besides, the perception and understanding are not significantly influence the financial report quality. The result of beta value shows that the business size strengthen the bookkeeping perception variable and weaken the understanding variable towards financial report quality. While the educational leverage strengthen the understanding variable and weaken the perception variables even all of them are not significantly influenced.
\end{abstract}

Keywords: MSME; bookkeeping; understanding; financial report quality

\section{INTRODUCTION}

The Government of Indonesia, especially the Ministry of Cooperatives and Micro Small Medium Enterprises is currently inviting the community to be creative in developing small micro enterprises in order to develop entrepreneurship. People both rural and urban, ranging from young to advanced age run the home industry. Culinary products typical souvenirs of the region using both farming and non farming materials. Processing also varied, from simple to very creative in terms of taste, process, and packaging. Culinary entrepreneurs are competing to make the packaging as attractive as possible so that it is easy to be glimpsed by consumers. Dewi Shanti Nugrahani (2011) revealed that one of the

\footnotetext{
${ }^{1}$ cahyani031084@gmail.com; STIE AUB Surakarta, Indonesia

2imron aub@ymail.com; STIE AUB Surakarta, Indonesia
} 
problems faced by UMKM is the problem of capital and marketing. The perpetrators of SMEs need to find new boredom to be able to increase sales turnover.

One of the problems that is often neglected by the business actors of SMEs is about financial management, including what happened to SMEs in the city of Surakarta. The impact of the neglect of financial management may not be obvious, but without effective accounting methods, it is unlikely that managers will be able to fully understand their business. Accounting is a key indicator of the performance of a business. The information generated by the accounting records is useful for decision making so as to improve the effectiveness of business management (Warren et al, 2005). Such information enables the perpetrators of MSMEs in identifying and predicting financial problems that may arise, then can take appropriate and quick steps to overcome them. Based on the above background, the researchers wanted to further identify the factors that affect the perception and understanding of SMEs perpetrators of the importance of bookkeeping systems and financial reports.

\section{LITERATURE REVIEW}

\section{Micro Small Medium Entreprises}

Based on Law no. 20 of 2008 on Micro Small Medium Enterprises, the definition of business is as follows:

1. Micro Enterprise is productive business owned by individual and / or individual business entity fulfilling the criteria of Micro Business as regulated in this Law.

2. Small-scale business is a stand-alone productive economic enterprise undertaken by an individual or a business entity that is not a subsidiary or not a branch of a company owned, controlled, or becomes part directly or indirectly from a Medium-Sized Enterprise or a Large Enterprise criteria for small-scale enterprises as referred to in this Law.

3. Medium Business is a stand-alone productive economic enterprise, conducted by an individual or a business entity which is not a subsidiary or branch of a company owned, controlled, or becomes part directly or indirectly with a Small Business or a Large Business net or annual sales proceeds as provided in this Law. Large Business is a productive economic enterprise undertaken by a business entity with a net worth or a greater annual sale out of the Medium Enterprise, which includes state-owned or private national enterprises, joint ventures, and foreign businesses conducting economic activity in Indonesia.

Based on the capital, the type of business can be categorized as follows:

1. Micro Business Criteria are as follows:.

a. Having a net worth of at most Rp50,000,000.00 (fifty million rupiah) excluding land and building of business premises; or

b. Has annual sales of at most Rp300,000,000.00 (three hundred million rupiah).

2. Small Business Criteria are as follows:

a. Having net worth of more than Rp50,000,000.00 (fifty million rupiah) up to a maximum of Rp500,000,000.00 (five hundred million rupiah) excluding land and building of business premises; or

b. Has annual sales of more than Rp300,000,000.00 (three hundred million rupiahs) up to a maximum of $\mathrm{Rp} 2,500,000,000.00$ (two billion five hundred million rupiah).

3. Medium Business Criteria are as follows:

a. Having a net worth of more than Rp500,000,000.00 (five hundred million rupiah) up to a maximum of Rp10,000,000,000.00 (ten billion rupiah) excluding land and building of business premises; or

b. Has annual sales of more than Rp2,500,000,000.00 (two billion five hundred million rupiah) up to a maximum of Rp50,000,000,000.00 (fifty billion rupiahs). 
Until now, if categorized into the understanding and the amount of capital, the culinary business actors souvenirs typical of most areas are still included in the micro industries that do not have large capital and large turnover. It is also due to the support of infrastructure facilities that do not increase the selling value of culinary products souvenirs typical of the region. Profit taken from the sale price is also not too large.

\section{SME Manufacturing Accounting System}

A manufacturing company is a company whose activities process raw materials into finished goods then sell the goods (Horngren, 2006). Production activities in the manufacturing company is the processing of raw materials into finished goods. The business cycle is concentrated in production and management activities related to the calculation and control of production costs which is the most important component for companies engaged in industry. Basically the cost of production can be grouped into 3, namely:

a. The cost of the raw material is the cost of all the raw materials that will eventually become part of the cost object. The cost of raw materials directly includes freight charges, sales taxes, and import duties.

b. Direct labor cost which is the cost for labor that handles directly the production process or that can be directly identified on the finished goods.

c. Factory overhead costs that are factory costs other than raw materials and direct labor or all manufacturing costs associated with cost objects. For example cost of materials, indirect labor cost, and repair and maintenance cost.

These costs are accumulated into three inventories: raw materials, processed goods, and finished goods. Inventories of raw materials are raw materials that have not undergone processing. Goods in the process are all items that have been entered in the process of processing. Finished goods are goods that are ready for sale.

Accounting cycle to be made is started from the transaction then the evidence appears transactions and then made a journal, then ledger, followed by a work sheet and the last is the financial statements. Generally accepted accounting principles require that both the balance sheet and profit / loss statements be supplemented by a cash flow statement when reported (Warren et al, 2006).

Murniati (2002) examines the factors that influence the preparation and use of accounting information in small companies in Central Java with a sample of 283 small and medium entrepreneurs. It is found that the characteristics of the owner / manager (lead time, managerial / owner formal education and accounting training followed by manager / owner) and characteristics of small and medium enterprises (age of company, industry sector, and business scale) significantly positively influence on the preparation and use accounting information on the company. Pinasti's research (2001) found that small traders in traditional markets in Banyumas district did not conduct and did not use accounting information in the management of their business. Decisions in business management are mostly based on nonaccounting information and a cursory observation of the market situation. In general they consider accounting information unimportant. Reasons put forward include: they feel too much trouble with the implementation of such accounting records and importantly they earn a profit without burdened with the implementation of accounting. They have not felt the benefits of bookkeeping. Baas and Schrooten (2006) in his research mentions that banks in the distribution of credit to MSME using Soft Information \& Hard Information. Soft Information using the technique of Relationship Lending namely the channeling of credit on the basis of trust and relationships that have been well established between banks and employers. Hard information includes: 1) Financial Statement Lending, ie by using financial statements that have been in accordance with accounting standards applicable as a source of information for lending, 2) Assets Based Lending ie by using information related to assets 
used as collateral, 3) Credit Scoring, the use of statistical techniques using financial data from financial statements and also creditworthiness and backgrounds of MSME owners to be ranked. Baas and Schrooten concluded that almost all over the world UMKM has difficulty in obtaining credit banking. One of the causes is the existence of information keterbatasa able to be given by UMKM to external parties. Suggestions given in the study are the importance of accounting standards that are able to accommodate the needs of UMKM entrepreneurs, in order to assist SMEs in providing better quality financial information. Cziráky et al. (2005) examined the factors that led to the low lending of MSMEs in Croatia. The credit program of SMEs run by the Croatian government turned out to be low credit distribution, even though the government has subsidized the interest rates and the supply of funds that are considered sufficient credit for MSMEs. Their results show that the average banking is inconsistent in terms of the use of credit approval criteria. The inconsistency is due to differences in skills and knowledge in credit assessment of bank employees in the country. There is a preference by banks to more credit approval for small amounts and for smaller companies that are safer. This condition occurs due to risk averse banking due to lack of information in the credit assessment process.

Jati et al. (2004) stated that at this time most MSMEs still do not hold accounting bookkeeping and reporting properly. Implementation of accounting bookkeeping to provide informative financial statements is still difficult for MSMEs. This is due to the limited knowledge in accounting bookkeeping, the complexity of the accounting process, and the assumption that the financial statements are not important for MSMEs (Said 2009). Maseko and Manyani (2011) also found that the majority of SMEs in Zimbabwe do not have complete accounting records due to limited accounting knowledge. Perception is a process of the individual in selecting, managing, and interpreting a stimulus it receives into an assessment of what is in the vicinity (Schiffman and Kanuk 2010). Perception becomes a person's starting point in assessing and running a thing, including financial accounting and reporting. Given that bookkeeping and reporting are important for business growth, it will encourage them to start doing bookkeeping or for those who have started to further improve the quality of their financial statements.

There are several things that may affect the perception of entrepreneurs related to the importance of bookkeeping and understanding of financial reporting for the growth and development of business such as the last level of education, educational background, size of business, and long standing business. A higher level of education will increase the ability to absorb (including acquisition, assimilation, transformation and exploitation) of new knowledge (Gray 2006; Van Hermert et al., 2011). Murniati (2002) found that entrepreneurs with low levels of formal education tend to lack adequate preparation and use of accounting information compared to entrepreneurs with higher formal education. This is because the accounting material obtained at higher education level. In addition, the background of UMKM entrepreneurs can affect perceptions related to the importance of financial bookkeeping and reporting for the growth and development of business. Knowledge of accounting and usability of the financial statements is primarily obtained if a person is studying with an accounting department. Entrepreneurs with accounting backgrounds are believed to have a better perception of the Financial Statement than entrepreneurs with nonaccounting educational backgrounds.

Pinasti (2001) found that the size of the business is a factor that is difficult to separate with the environment of UMKM entrepreneurs. The size of the business can affect the entrepreneur's thinking related to the complexity and the higher level of corporate transactions so it is expected that the greater the size of the business can encourage someone to think and learn related solutions to deal with it. Large business measures have implications that firms have greater resources and are also better able to hire better-skilled employees 
(Gray 2006). The size of the business is expected to have a positive effect on the perception of UMKM.

Long standing a business is suspected to have a positive influence on the perception of UMKM entrepreneurs regarding Financial Statements. According to Amburgey et al. (1993), in Anderson and Eshima (2011), the longer business life provides the advantage of having a routine structure and process that disciplines every corporate action. Included in the process is the bookkeeping process. Das and Dey (2005) found a positive relationship between the age of SMEs business with the frequency of doing the bookkeeping regularly. MSMEs with a longer age who bookkeeping more regularly, are expected to have a better perception of the Financial Statements.

\section{METHOD, DATA AND ANALYSIS \\ Objective Reserach}

The aims of the research is to analyze the impact of bookkeeping perception and understanding towards financial report quality with Micro Small Mediaum Enterprise's owner demographic as moderation variable. This research analyzes Micro Small Medium Entreprise especially the owner of culinary micro small medium enterprises in Surakarta, Indonesia. The quality of Financial Report is examined based on perception and financial report understanding of the owner.

\section{Research Method}

The population is the whole subject of the study. Population research is conducted if one wants to examine all the elements present in the research area. Studies in his research are also called censuses (Arikunto, 2011: 36). The population in this research is 33 member of UMKM Surakarta forum. Determination of samples in this study using census sampling, where all members of the population are sampled (Sugiyono, 2014) so that the sample of this study is 33 members of the Forum UMKM Surakarta. In the data analysis used the concept of analysis process using the concept developed Ghozali (2011). The influence relationship will be used moderation analysis. In this research, demographic variable that is last education and business age is placed as moderator variable. Interaction analysis is a technique of statistical analysis developed from multiple linear regression analysis. Mathematically, this analysis is nothing but multiple linear regression analysis of standardized data.

Thus, statistical software capable of performing multiple linear regression can also be used for interaction analysis. The main subjects of this analysis are the correlated variables. This analysis bases itself on the relationship model among variables that was determined before by the researchers. The statistical analysis technique used in this research is interaction analysis.

\section{CONCLUSION}

Parsial and Simultan Regression Result of $\mathrm{Y}=$ constant $+\mathrm{x} 1$ SME_PERCEPTi $+\mathrm{x} 2$ SME_Understanding+ ei

Table 1. F test result

\begin{tabular}{llll}
\hline Model & Sum of Square & F & Sig \\
\hline Regression & 2,617 & 1,430 & 0,225 \\
Residual & 27,444 & & \\
Total & 30,061 & & \\
\hline
\end{tabular}

Source : processed data 
From the $F$ test result, the calculated $F$ value is 1.430 with probability 0,255 . Because probability is greater than 0.05 , the regression model can not be used to predict the Quality of Financial Statement or it can be said that Perception and Understanding together have no effect on Quality of Financial Report.

Table 2. Regression test result

\begin{tabular}{llll}
\hline Model & $\mathrm{B}$ & $\mathrm{t}$ & $\mathrm{Sig}$ \\
\hline Constant & 0,664 & 0,386 & 0,702 \\
$\mathrm{X} 1$ & 0,182 & 1,396 & 0,173 \\
$\mathrm{X} 2$ & 0,115 & 1,219 & 0,232 \\
\hline
\end{tabular}

Source : processed data

From the regression test, the formulation is $\mathrm{Y}=0,664+0,182 \mathrm{X} 1+0,115 \mathrm{X} 2$. The two independent variables included in the regression model, they are not significant. It can be seen from the probability significance for Perception (X1) of 0.173 and Understanding (X2) of 0.232 .

\section{Moderating Regression Test 1}

Regression test of moderation phase 1 is to know the effect of leverage education as moderation variable (Z1) on variable of perception of business owner about financial report (X1) to quality of financial report (Y). The moderation variable, education leverage (Z1) has a positive and significant effect. This can be seen from the probability significance for Perception (X1) of 0.077 and Education leverage (Z1) of 0.011 . The equation from the result is $\mathrm{Y}=-1,213+0,219 \mathrm{X} 1+0,754 \mathrm{Z} 1$.

Table 3. Moderating Regression test $1 \mathrm{~A}$

\begin{tabular}{llll}
\hline Model & B & t & Sig \\
\hline Constant & $-1,213$ & $-0,697$ & 0,491 \\
X1 & 0,219 & 1,831 & 0,077 \\
Z1 & 0,754 & 2,729 & 0,011 \\
\hline
\end{tabular}

Source : processed data

Table 4. Moderating Regression test 1B

\begin{tabular}{lccc}
\hline Model & $\mathrm{B}$ & $\mathrm{t}$ & Sig \\
\hline Constant & $-11,238$ & $-1,271$ & 0,214 \\
X1 & 1,033 & 1,447 & 0,159 \\
Z1 & 4,391 & 1,391 & 0,175 \\
Z1X1 & $-0,296$ & $-1,156$ & 0,257 \\
\hline
\end{tabular}

Source : processed data

The variables included in the regression model, none have a significant effect. It can be seen from the probability significance for independent variable Perception (X1) of 0.159; moderating variable Education leverage $(\mathrm{Z} 1)$ of 0.175 and the interaction of moderating variable toward independent variable $(\mathrm{Z} 1 \mathrm{X} 1)$ of 0.257 . The equation from the result is $\mathrm{Y}=-$ $11,238+1,033 X 1+4,391 Z 1-0,296 Z 1 X 1$. From the table above, the beta resulting from the interaction effect of $\mathrm{Z} 1 \mathrm{X} 1$ to $\mathrm{Y}$ is negative, which means that moderation of $\mathrm{Z} 1$ weakens the effect of $\mathrm{X} 1$ on Y. Although it weakens, the effect is also not significant. Based on the result above, by compare the influence between $\mathrm{Z} 1$ to $\mathrm{Y}$ and $\mathrm{Z} 1 \mathrm{X} 1$ to $\mathrm{Y}$ result is significant, then $\mathrm{Z} 1$ is predictor moderating variable. 


\section{Moderating Regression Test 2}

Regression test of moderation phase 2 is to know the effect of business size moderation variable (Z2) on variable of business owner perception about financial statement (X1) to quality of financial report (Y).

Table 5. Moderating Regression test $2 \mathrm{~A}$

\begin{tabular}{lccc}
\hline Model & $\mathrm{B}$ & $\mathrm{t}$ & $\mathrm{Sig}$ \\
\hline Constant & 3,055 & 1,977 & 0,057 \\
$\mathrm{X} 1$ & 0,117 & 0,966 & 0,342 \\
Z2 & $-0,450$ & $-2,326$ & 0,027 \\
\hline
\end{tabular}

Source : processed data

Of the two variables included in the regression model, one of which is moderating variable business size (Z2) has a negative and significant effect. This can be seen from the probability significance for Perception (X1) of 0.342 and business size (Z2) of 0.027 . The equation from the result is $\mathrm{Y}=3,055+0,117 \mathrm{X} 1-0,450 \mathrm{Z} 2$.

Table 6. Moderating Regression test 2B

\begin{tabular}{lccc}
\hline Model & $\mathrm{B}$ & $\mathrm{t}$ & Sig \\
\hline Constant & 3,698 & 0,721 & 0,477 \\
X1 & 0,064 & 0,151 & 0,881 \\
Z2 & $-0,716$ & $-0,351$ & 0,727 \\
Z2X1 & 0,022 & 0,132 & 0,896 \\
\hline
\end{tabular}

Source : processed data

Of the three variables included in the regression model, none have a significant effect. This can be seen from the probability significance for Perception (X1) of 0.881 ; moderating variable business size (Z2) of 0.727 and the interaction moderation variable between independent varibale and moderating variable (Z2X1) of 0.896 . The equation from the result is $\mathrm{Y}=3,698+0,0064 \mathrm{X} 1-0,716 \mathrm{Z} 2+0,022 \mathrm{Z} 2 \mathrm{X} 1$. From the table above, the beta resulting from the interaction effect of $\mathrm{Z} 2 \mathrm{X} 1$ on $\mathrm{Y}$ is positive, which means that moderation of $\mathrm{Z} 2$ amplifies the effect of $\mathrm{X} 1$ on $\mathrm{Y}$. Although it amplifies, the effect is not significant. Based on the above result, because one of the influence between $\mathrm{Z} 2$ to $\mathrm{Y}$ and $\mathrm{Z} 2 \mathrm{X} 1$ to $\mathrm{Y}$ result is significant, then $\mathrm{Z} 2$ is predictor moderating variable.

\section{Moderating Regression Test 3}

Regression test of moderation phase 3 is to know the effect of education moderation variable (Z1) on variable of financial statement comprehension (X2) to quality of financial report (Y).

Table 7. Moderating Regression test 3A

\begin{tabular}{lccc}
\hline Model & $\mathrm{B}$ & $\mathrm{t}$ & Sig \\
\hline Constant & 1,506 & 1,773 & 0,086 \\
X2 & 0,045 & 0,494 & 0,625 \\
Z1 & 0,614 & 2,111 & 0,043 \\
\hline
\end{tabular}

Source : processed data

Of the two variables included in the regression model, one of which is education leverage (Z1) has a positive and significant effect. This can be seen from the probability significance for the Understanding (X2) is 0.625 (more than 0,05) and Education leverage (Z1) is 0.043 (less than 0,05). The equation from the result is $\mathrm{Y}=1,506+0,045 \mathrm{X} 2+0,614 \mathrm{Z1}$. 
Table 8. Moderating Regression test 3B

\begin{tabular}{lccc}
\hline Model & $\mathrm{B}$ & $\mathrm{t}$ & Sig \\
\hline Constant & 2,596 & 1,003 & 0,324 \\
X2 & $-0,149$ & $-0,336$ & 0,740 \\
Z1 & 0,204 & 0,211 & 0,834 \\
Z1X2 & 0,072 & 0,447 & 0,658 \\
\hline
\end{tabular}

Source : processed data

Of the three variables included in the regression model, none have a significant effect. This can be seen from the probability significance for Understanding (X2) of 0.740; moderating variable Education leverage $(\mathrm{Z} 1)$ of 0.834 and the interation of moderating variable towards independent variable (Z1X2) of 0.658. The equation from the result is $Y=2,596-0,149 \mathrm{X} 2+$ $0,204 \mathrm{Z} 1+0,072 \mathrm{Z} 1 \mathrm{X} 2$. From the table above, the beta resulting from the interaction effect of Z1X2 on $\mathrm{Y}$ is positive, which means that moderation of $\mathrm{Z} 1$ amplifies the effect of $\mathrm{X} 2$ on Y. Although it strengthens but the effect is not significant. Based on the above result, because one of the influence between $\mathrm{Z} 1$ to $\mathrm{Y}$ with $\mathrm{Z} 1 \mathrm{X} 2$ to $\mathrm{Y}$ result is significant, then $\mathrm{Z} 1$ is predictor moderating variable.

\section{Moderating Regression Test 4}

Regression analysis of moderation step 4 is to know the effect of business size moderation variable (Z2) on variable of financial statement comprehension (X2) to quality of financial report (Y).

Table 9. Moderating Regression test 4A

\begin{tabular}{lccc}
\hline Model & B & t & Sig \\
\hline Constant & 4,072 & 5,931 & 0,000 \\
X2 & 0,070 & 0,803 & 0,428 \\
Z2 & $-0,458$ & $-2,365$ & 0,025 \\
\hline Source & & &
\end{tabular}

Source : processed data

Of the two variables included in the regression model, one of which is moderating variable business size (Z2) has a negative and significant effect. This can be seen from the probability significance for Understanding (X2) of 0.428 and business size (Z2) of 0.025 (less than 0.05). The equation from the result is $\mathrm{Y}=4,072+0,070 \mathrm{X} 2-0,458 \mathrm{Z} 2$.

Table 10. Moderating Regression test 4B

\begin{tabular}{lccc}
\hline Model & B & t & Sig \\
\hline Constant & 3,990 & 2,698 & 0,012 \\
X2 & 0,086 & 0,323 & 0,749 \\
Z2 & $-0,423$ & $-0,722$ & 0,476 \\
Z2X2 & $-0,007$ & $-0,063$ & 0,950 \\
\hline
\end{tabular}

Source : processed data

Of the three variables included in the regression model, none have a significant effect. It can be seen from the probability significance for Understanding (X2) of 0.749 ; moderating variable business size (Z2) of 0.476 and the interaction of moderating variable and independent variable (Z2X2) of 0.950 . The equation from the result is $Y=3,990+0,086 \mathrm{X} 2$ $0,423 \mathrm{Z} 2-0,007 \mathrm{Z} 2 \mathrm{X} 2$. From the table above, the beta resulting from the interaction effect of $\mathrm{Z} 2 \mathrm{X} 2$ on $\mathrm{Y}$ is negative, which means that moderation of $\mathrm{Z} 2$ weakens the effect of $\mathrm{X} 2$ on $\mathrm{Y}$. Although it weakens but the effect is not significant. Based on the above result, because one 
of the influence between $\mathrm{Z} 2$ to $\mathrm{Y}$ with $\mathrm{Z} 2 \mathrm{X} 2$ to $\mathrm{Y}$ result is significant, then $\mathrm{Z} 2$ is predictor moderating variable.

Table 10. Result Summary

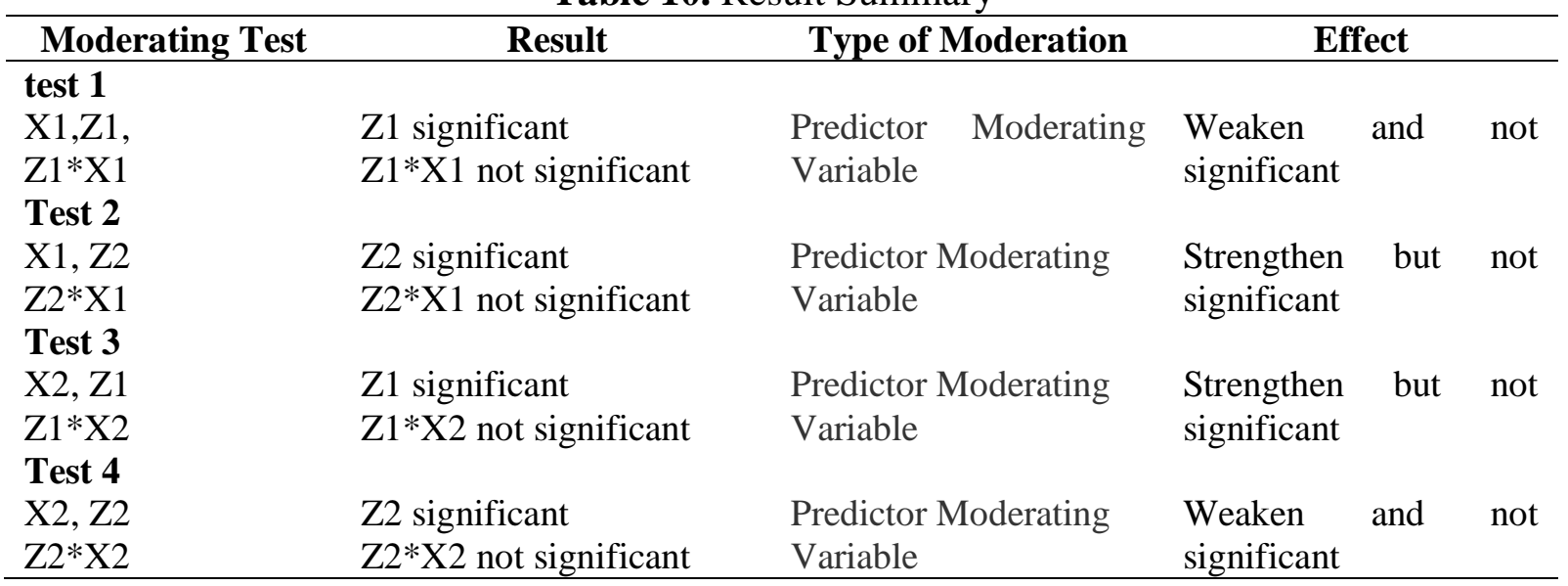

\section{MANAGERIAL IMPLICATION/LIMITATION AND SUGGESTIONS}

The results of this study indicate that the education moderation variables (Z1) and business size (Z2) are the variables belonging to the Moderator Predictor (Predictor Moderation Variable) category. This means that this moderation variable only acts as a predictor variable (independent) in the established relationship model

The implication of this research is that the education leverage and busness size as moderating variables is not suitable method for the SMSE because they are just predictors variables.. The next research can deepen this study by using other variables as moderating variables such as length of business, gender, number of capital owned by entrepreneurs. Besides, the education leverage and the business size can be moderating variables in different kinds of business.

\section{REFERENCES}

Audretsch, D. B. and J.A. Elston. 1997. Financing the German Mittelstand. Small Business Economics, 9, 97-110.

Baas, T. dan M. Schrooten. 2006. Relationship Banking and SMEs: A Theoretical Analysis. Small Business Economics, 27.

Basri, Y.Z. and M. Nugroho. 2009. Ekonomi Kerakyatan: Usaha Mikro, Kecil, dan Menengah. Jakarta: Penerbit Universitas Trisakti.

Cressy, R. 2006. Why do Most Firms Die Young? Small Business Economics, 26, 103-116.

Cziráky, D., S. Tiśma, and A. Pisarović. 2005. Determinant of Low Approval Rate In Croatia. Small Business Economic,25, 347-372.

Das, A.K. and N.B. Dey. 2005. Financial Management and Analysis Practices in Small Business: An Exploratory Study in India. Working Paper, http://sbaer.uca.edu/research/icsb/2005/paper53.pdf.

Departemen Koperasi. 2010. Berita. Diunduh tanggal 22 Agustus 2010. www.depkop. go.id

Gray, C. 2006. Absorptive Capacity, Knowledge Management and Innovation in Entrepreneurial Small Firms. International Journal of Entrepreneurial Behaviour \& Research, 12 (6), 345-360.

Jati, H., B. Bala, dan O. Nisnoni. 2004. Menumbuhkan Kebiasaan Usaha Kecil Menyusun Laporan Keuangan. Jurnal Bisnis dan Usahawan, II (8), 210-218. 
Kirschenmann, K. and L. Norden. 2010. The Relation between Borrower Risk and Loan Maturity in Small Business Lending. Working paper. http://terberger.bwl.uniannheim.de/fileadmin/images/ itarbeiter/KirschenmannNorden/ Aug2010.pdf

Mac an Bhaird, C. and B.M. Lucey. 2010. Determinants of Capital Structure I Irish SMEs. Small Business Economics, 35 (3), 357-375.

Maseko, N. and O. Manyani. 2011. Accounting Practices of SMEs in Zimbabwe: AnInvestigative Study of Record Keeping for Performance Measurement (A Case Study of Bindura). Journal of Accounting and Taxation, 3 (8), 171-181.

Mazanai, M. and O. Fatoki. 2012. Perceptions of Start-up Small and Medium-Sized Enterprises (SMEs) on the Importance of Business Development Services Providers (BDS) on Improving Access to Finance in South Africa. Journal of Social Science, 30 (1), 31-41.

Murniati. 2002. Analisis Faktor-Faktor yang Mempengaruhi Penyiapan dan Penggunaan Informasi Akuntansi pada Pengusaha Kecil dan Menengah di Jawa Tengah. Tesis, Universitas Diponegoro.

Pinasti, M. 2001. Penggunaan Informasi Akuntansi dalam Pengelolaan Usaha Para Pedagang Kecil di Pasar Tradisional Kabupaten Banyumas. Jurnal Ekonomi,Bisnis, dan Akuntansi, 1 (3).

Schiffman, L.G and L.L. Kanuk. 2010. Consumer Behavior. New Jearsey: Pearson Education, Inc.

Siregar, S.V., S.N. Harahap, dan Wasilah. 2011. Evaluasi Tantangan Penerapan Standar Akuntansi Entitas Tanpa Akuntabilitas Publik (SAK ETAP) untuk Usaha Kecil dan Menengah. Proposal Hibah RUUI.

Van Hemert, P., E. Masurel, and P. Nijkamp. 2011. The Role of Knowledge Sources of SME's for Innovation Perception and Regional Innovation Policy. Working paper. http://dare.ubvu.vu.nl/ bitstream/1871/24072/1/rm\%202011-39.pdf.

Warsono, S. dan E. Murti. 2010. Akuntansi UMKM Ternyata Mudah Dipahami dan Dipraktikkan. Yogyakarta: Asgard Chapter Winarno.

Zimele, A. 2009. The SMME Business Toolkit.New York: SBDA(Pty) Ltd 